\title{
Industrial Park and Foreign Investment for Sustainable Development in Indonesia
}

\author{
Hasan Mustapa1, Melda Ria Juwita², Yusuf Gumilar Sukma3 \\ ${ }^{1}$ Sunan Gunung Djati State Islamic University, Faculty of Social and Political Science, Bandung, \\ Indonesia. \\ ${ }^{2}$ The School of Geography, Nanjing Normal University, China \\ ${ }^{3}$ The School of Urban Design, Faculty of Engineering, Wuhan University, China: \\ *Corresponding Author E-mail: kangmoez@uinsgd.ac.id
}

\begin{abstract}
In this era of globalization, foreign investment no longer needs to be seen as a threat. On the other hand, foreign investment can be considered as a driving force for national development, including for Indonesia as a developing country, including the construction of Industrial Parks. This study aims to determine the potential and challenges of foreign investment in the development of industrial estates in Indonesia. This paper uses a qualitative descriptive method, where this study describes events that occur and is intended to describe existing phenomena, both natural and human engineering. As a result, this paper finds that the Indonesian government has begun to improve infrastructure so that it is also sufficient to be one of the supporting factors. With a good location and infrastructure, the company's business activities become more effective. And more importantly, the Indonesian government is also willing to provide some fiscal facilities and licensing facilities related to company activities even though they are slightly contrary to sustainable development. Therefore, this research will contribute to the process of increasing foreign investment for sustainable development in Indonesia.
\end{abstract}

Keywords: Industrial park, foreign direct investment, sustainable development, eco-efisiensi.

\begin{abstract}
Abstrak
Di era globalisasi ini, penanaman modal asing tidak perlu lagi dipandang sebagai ancaman. Sebaliknya, penanaman modal asing dapat dianggap sebagai motor penggerak pembangunan nasional, termasuk bag Indonesia sebagai negara berkembang, termasuk dengan pembangunan Industrial Park. Penelitian ini bertujuan untuk mengetahui potensi dan tantangan investasi asing dalam pengembangan kawasan industri di Indonesia. Tulisan ini menggunakan metode deskriptif kualitatif, dimana penelitian ini menggambarkan peristiwa yang terjadi dan dimaksudkan untuk menggambarkan fenomena yang ada, baik alam maupun rekayasa manusia. Hasilnya, makalah ini menemukan bahwa pemerintah Indonesia telah mulai memperbaiki infrastruktur sehingga juga memadai untuk menjadi salah satu faktor pendukung. Dengan lokasi dan infrastruktur yang baik, kegiatan usaha perusahaan menjadi lebih efektif. Dan yang lebih penting lagi, pemerintah Indonesia juga bersedia memberikan beberapa fasilitas fiskal dan fasilitas perizinan terkait kegiatan perusahaan walau sedikit bertentangan dengan pembangunan berkelanjutan. Oleh karena itu, penelitian ini akan berkontribusi pada proses peningkatan investasi asing untuk pembangunan berkelanjutan di Indonesia.
\end{abstract}

Kata Kunci: Kawasan industri, investasi asing langsung, pembangunan berkelanjutan, eko-efisiensi.

\section{INTRODUCTION}

Economic globalization is still a major trend to be discussed following today's global economy growth. Nevertheless, developed countries have now played a leading role in the cycle of globalization's economic progress. Today, economic progress and innovation in IT and telecommunications are now

* Copyright (c) 2021 Hasan Mustapa et.al

This work is licensed under a Creative Commons Attribution-ShareAlike 4.0 International License

Received: July 8, 2021; In Revised : July 17, 2021; Accepted : July 23, 2021 
recognize as the driving force behind economic globalization (Albarran, 2016). The increasing number of developed countries make the foreign direct investment (FDI) is a feature of the growth of global economic globalization. Total FDI hit an all-time high of US\$ 1.833 billion in 2007 (Weissleder, 2009). A very high FDI flow has a significant advantage in achieving host country economic growth (Forte \& Moura, 2013).

FDI in Indonesia is diversified by sector. The manufacturing industry continues to lead in Indonesia until 2019, driven by power, gas and water supply, which began to grow dramatically relative to other sectors at $48.2 \%$ in 2018 and $62.4 \%$ in the first quarter in 2019. The most massive rise in FDI flows in Indonesia occurred in 2013, which amounted to IDR 348.82 trillion, up over IDR 100 trillion from inflows in 2012 (IICB, 2019). Indonesia ranked fourth as the most attractive country for investment purposes, Indonesia rose four scores from the previous poll after the United States, China, and India (Maelani et al., 2019; UNCTAD, 2017). In 2018, Indonesia became Southeast Asian countries ' largest recipient of capital from Chinese investors by earning USD 171.11 trillion, followed by Vietnam with USD 151 trillion and Cambodia with USD 103.96 trillion in third place. China's investment is the 3rd largest for foreign investment in Indonesia, along with Singapore and Japan. China's Belt and Road Initiative (BRI) economic program has had an impact on the enhancement of investment schemes (IICB, 2019).

Industrial park construction is a significant component and innovative method in the BRI plan, which is expected to promote inclusive globalization through the development of new forms of cooperation between China and Indonesia. Political flexibility has implications for the growth of industrial parks abroad, a classic concept in international political geography that explores the relationship between national and global politics. Industrial park establishment can increase investment funds, and there will be indications of the potential and challenges that will be faced (Tao et al., 2018). Indonesia's ongoing efforts in developing sustainable development planning indeed commendable. However, all this time the effort is still biased in ethnocentric west, and can consider local wisdom both tradition, religion and sociocultural scope that already exists. So that it can add sustainable development plans effectively (Dariah \& All., 2019).

In the context of sustainability, economic development must accompanied by environmental management and social progress so that it can sustained for future generations. Countries with unsustainable trajectories can basically increase investment to record positive gains in the level of wealth growth, or reduce consumption to levels that can maintained by their productive base. At the moment, stakeholders are beginning to understand that non-renewable resources can, and must, function as drivers of economic growth and poverty reduction (Arrow \& All., 2012). Several previous studies as Jufrida et al (2016), Kambono \& Marpaung (2020) and Mulya (2015) have not fully described the investment system, especially those related to sustainable development. For this reason, this research will contribute to conceptions in the investment sector, especially in the investment sector for sustainable development.

\section{RESEARCH METHOD}

This study used the literature review method with the descriptive analysis method by comparing it with previous studies linked to Industrial Park development in Indonesia and other countries and including evidence derived from data from Indonesian foreign investment agencies. This paper uses a descriptive qualitative method, in which this research describes the events that occur and is intended to describe and describe existing phenomena, both natural and man-made, with a focus on characteristics, quality, and inter-relationships between activities. Furthermore, descriptive research does not provide treatment, manipulation, or alteration of the variables studied, but rather describes a condition as it 
currently exists. As well as literature review studies and see the facts in the field to be more significant information. The two theories that we will use in this research are Sustainable Development and Ecoefficiency.

\section{Sustainable Development}

Sustainable development emphasizes the importance of shifting away from risky socioeconomic activities and becoming more involved in activities that have positive environmental, economic, and social impacts (Ukaga et al., 2011). It also aims to make social progress, environmental balance and economic growth (Gossling-Goidsmiths, 2018; Zhai \& Chang, 2019). Sustainable development has become a buzzword in the development community, with numerous definitions, meanings, and interpretations. Taken literally, sustainable development only refers to development that can last indefinitely or for a limited time (Beckerman, 2017). Sustainable development is a central concept in global development policy and agenda, and it refers to development that meets the needs of the current generation without compromising future generations' ability to meet their own needs (Elliott, 2012).

\section{Eco-efisiensi}

Eco-efficiency has now been proposed as a concept to improve corporate environmental and social performance by enabling a practical approach to economic and environmental efficiency based on sustainability (Suh et al., 2014). This idea based on industrial estate-based environmental management. With this, there is potential to convert waste output into resource response. So as to minimize economic, social, and environmental costs, as well as avoiding excess use of raw materials. Increased efficiency is an effective way to decrease resource consumption (Dahmus, 2014). Based on this background, this article seeks to find out how foreign investment support for industrial estates development can encourage sustainable development. This study scheme shown in the following figure 1.

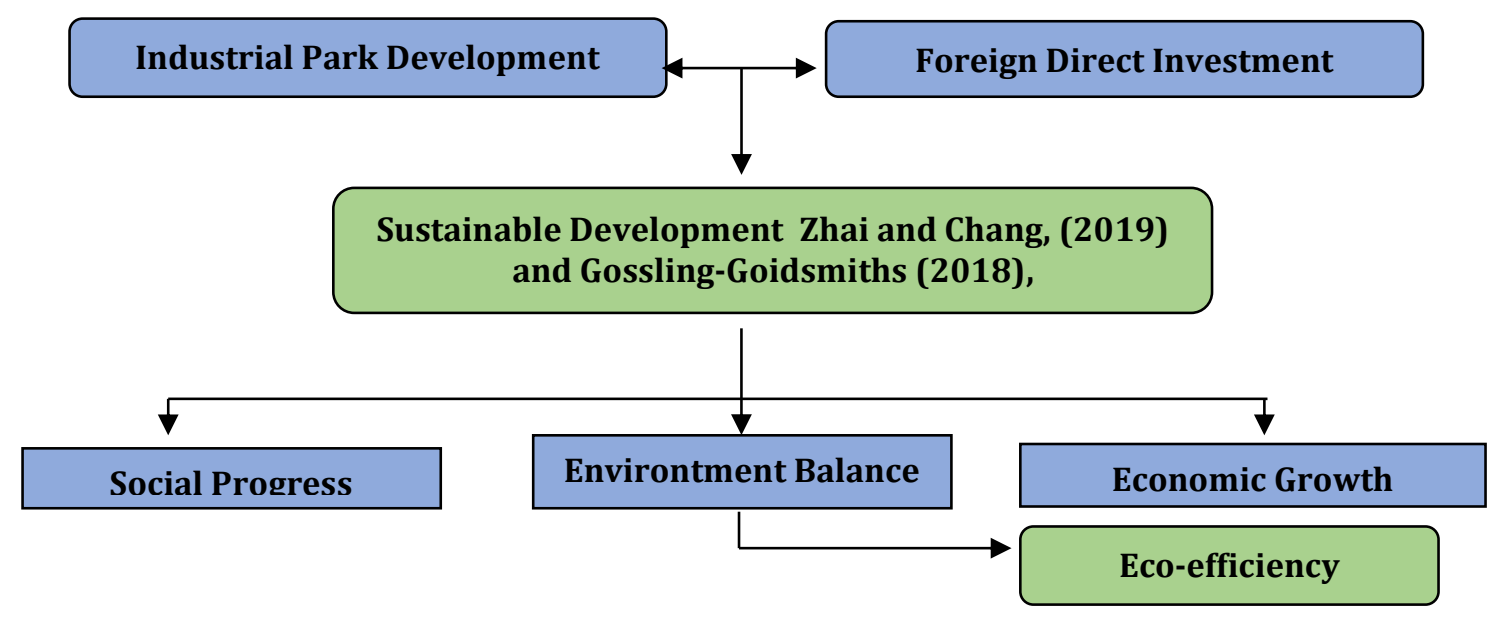

Figure 1. Conceptual Framework 


\section{RESULT AND DISCUSSION}

\section{Result}

\section{Foreign Direct Investment}

Foreign direct investment (FDI) may bring significant benefits to host countries (Kurtishi-Kastrati, 2013), several studies have studied how FDI contributes significantly to economic development and has a positive impact on a country's progress, especially for non-industrial and developing countries (Mehic et al., 2013). It also will increase the host country's availability of funds. Athukorala conducted research using an econometric model of cointegration and the time series data from 1959 to 2012 to analyze the FDI-GDP relationship in Sri Lanka (Athukorala, 2003). The results show that FDI has a positive effect on GDP in Sri Lanka, as well as a causal relationship between FDI and GDP. Lipsey also found that the FDI stream had a positive impact on the host (Lipsey, 1999).

Su and Liu have researched the effect of FDI and human capital on China's economic development from 1991 to 2010, using a city information panel in China. They analyzed economic growth determinants with an emphasis on the role of FDI and human resources. They also found that FDI had a positive effect on per capita GDP growth, which was reinforced by public social capital ownership (Su \& Liu, 2016).

Indonesia has a strong desire for foreign investment to fund the current account deficit and accelerate economic growth. With a growing contribution to GDP, foreign direct investment is projected to be the critical source of economic growth in addition to the government's infrastructure budget (Tao et al., 2018). Indonesia's GDP per capita continues to rise to $\$ 3,932$ in 2018 from $\$ 823$ in 2000 . As an emerging middle-and lower-income country, this archipelago nation had benefited a lot from poverty reduction, rising poverty rates by more than half since 1999 to 9.8 percent in 2018. Economic growth in Indonesia has increased, backed by substantial investment, low unemployment, and an active labor market (Bank, 2019).

\section{Investment in Indonesia}

There has been a rapid increase in Foreign Direct Investment (FDI) reaching Indonesia since 2010. Since then see figure 2 and figure 3, Indonesia has begun to join and sit on the foreign companies radar screen. It no longer underestimates Indonesia's attractiveness as a market. The cause was by reporting positive growth of 4.6 percent in 2009 as Indonesia was able to face the global crisis in 2008-2009. During the worldwide economy's recession, only China, India, and Indonesia reported positive growth. The following is an Indonesian description of the FDI.

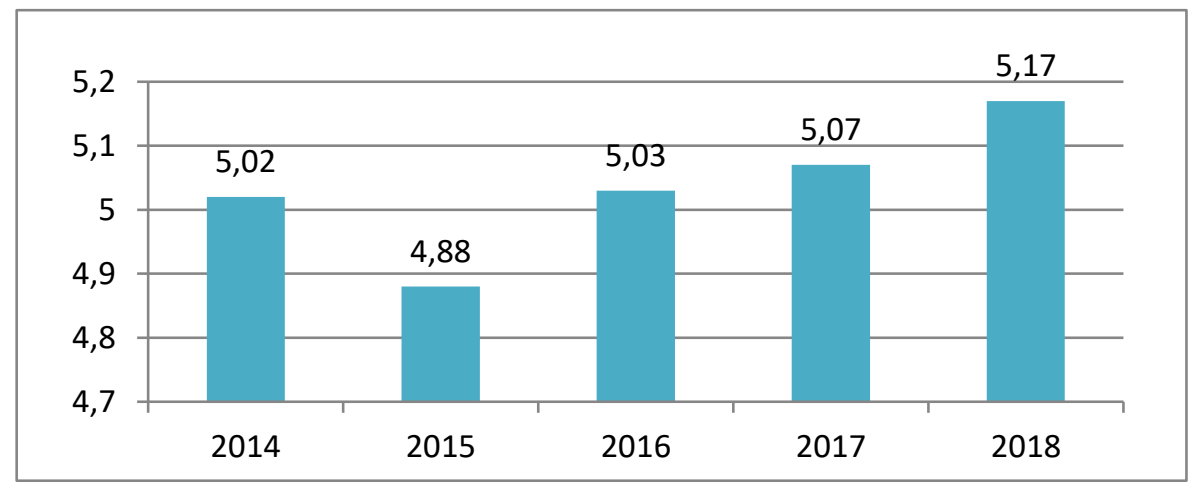

Figure 2. Percentage of Indonesia GDP Growth 
Khazanah Sosial, Vol. 3 No. 3: 147-159

Industrial Park and Foreign Investment for Sustainable Development in Indonesia Hasan Mustapa et.al

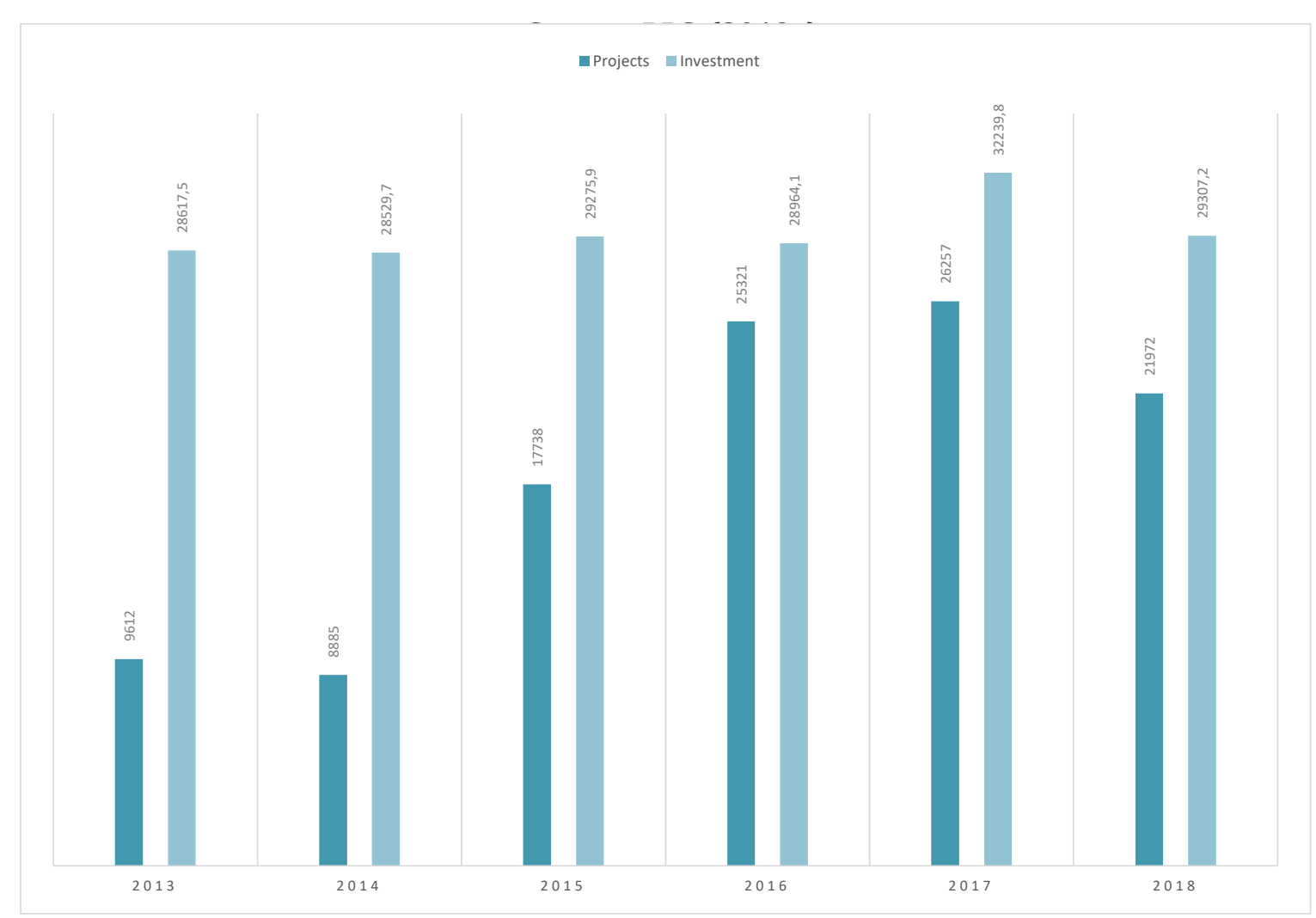

Source : BPS (2019b)

Figure 3. Projects and Investment of FDI in Indonesia

In the fourth quarter of 2017, Indonesia's investment stream hit its highest peak, touching an alltime high of US $\$ 32239.8$ million. Singapore is the largest source of investment, followed by the top five in the next year by Japan, China, Malaysia, and South Korea. Foreign investors also prefer the manufacturing sector as the leading market. Significant increases have occurred over the past three years in the energy, gas and water supply industries, as well as in the real estate and business services industry, which has experienced an increase in the type of investment since 2013. Thus investment has fluctuated for other sectors see figure 4.

Business convenience is one indicator, particularly in terms of facilities. Tambunan stated that infrastructure is the first in consideration of investment matters (Tambunan, 2007). Java Island still dominates the absorption of FDI inflow, especially in the West Java Province. That's because Java's infrastructure is good enough. As supply indicators, ports, airports, and highways are sufficient. The expansion of FDI flows has also begun to spread over time to other islands such as Sumatra, Kalimantan, and Papua. Foreign investors are actively starting to build industrial parks outside of Java on islands. Foreign investors began to venture to invest in islands other than Java, suggesting that the Indonesian government was successful in ensuring security and investment comfort.

Attracting trust in investment from other countries is still being pursued and is a challenging but achievable goal. From 2014, successively from Indonesia until 2016, Singapore, Japan, Malaysia and the Netherlands became investment subscription countries Chinese investors burst into the top five with a 17 percent share, followed by the same percentage the following year and became Indonesia's largest investor in the first quarter of 2019 with a 25.40 percent skyrocketing performance shifting Singapore's position as the first largest investor all this time. 
Khazanah Sosial, Vol. 3 No. 3 : 147-159

Industrial Park and Foreign Investment for Sustainable Development in Indonesia Hasan Mustapa et.al

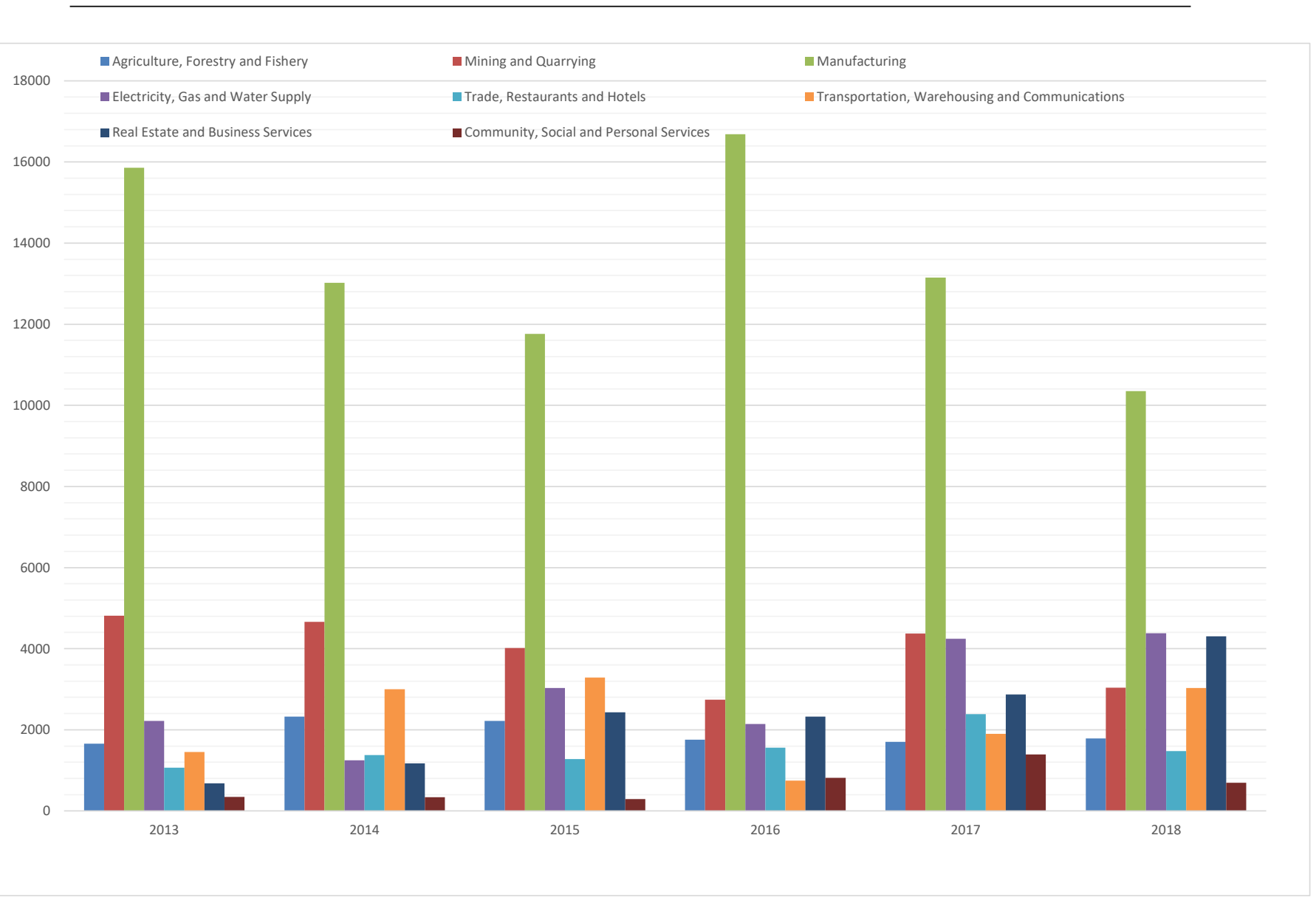

Source : BPS (2019a)

Figure 4. FDI Trends Sector in Indonesia

Recognizing the great benefits of rising economic growth from the FDI, the Indonesian government began to search for ways to attract foreign entrepreneurs to invest. Nevertheless, appreciation of FDI's importance is demonstrated by the issuance of the Foreign Investment Law of 1967 to attract foreign investment to build the national economy. With this regulation, the Investment Technical Committee has been formed. The Indonesian Investment Coordinating Board (IICB) was created in 1973, instead of the functions performed by the Investment Technical Committee, which is an agency at the ministry level and has been approved to grant approval and permission for foreign direct investment. Indonesia's government offers a variety of investment opportunity packages with all the conveniences, both inlicensing and regulating, to increase investor interest in Indonesia.

\section{Industrial Park Development}

An industrial estate is an area run by and marketed by private or public companies, which provides necessary infrastructure, for example, electricity, water and wastewater. An industrial estate is called an industrial park. It also provides a number of support services (such as permits and security) as well as property facilities. In Indonesia first industrial estates were developed in the 1970's, through the combined efforts of the local and provincial governments (Jakarta, Surabaya, Cilacap, Medan, Makassar and Lampung). A watershed moment in the development of industrial parks was Presidential Decree 53/1989 opening up the business of industrial property development to private companies, establishing law and 
Khazanah Sosial, Vol. 3 No. 3: 147-159

Industrial Park and Foreign Investment for Sustainable Development in Indonesia

Hasan Mustapa et.al

technical standards for the development and operation of these properties. In 1996, the presidential decree 41/1996 established the first industrial estates guidelines in Indonesia. The industrial estate is underlined as a center of manufacture supported by infrastructure, installations and services by Government Regulation No 24/2009. Industrial estates typically provide in Indonesia:

1. Infrastructure includes roads, water supply, drainage systems, wastewater systems, electricity, and telecommunications.

2. Employee housing, office space, hotels, fiber optic telecommunications cables, and specialized transportation services are all available.

3. Medical services, fire department, security, commercial services, and recreational area are all available.

Industries have the ability to plug into a ready for use factory with complete facilities or buy a parcel of land to build a factory tailored to specific production needs. Investors can also use a large range of manufacture and industrial activities. Some industrial parks offer the full package including permits and licenses processing with the competent authorities, and the recruitment of readily accessible employees from the local pool and from the rest of Indonesia.

Table 1. Industrial parks in Indonesia

\begin{tabular}{clcl}
\hline No. & Locations & Total (Ha) & Land area \\
\hline 1. & Java & 55 & $22,795.90$ \\
2. & Sumatera & 16 & $4,493.45$ \\
3. & Sulawesi & 2 & $2,203.00$ \\
4. & Kalimantan & 1 & 546 \\
\hline & Total & 74 & $30,038.35$ \\
\hline
\end{tabular}

Source : Salanto (2015)

Table 1 show The dominance of the number of industrial parks in Indonesia is still on the island of Java, covering an area of 22,795.90 hectares totaling 55 areas. A total of 13 regions are controlled by Indonesian State-Owned Enterprises or the public sector. While the remaining 61 areas are owned by the private sector. Foreign investors who have been subscribed to since long ago are Japan, USA, and Singapore, while for newcomers such as China, who have just begun to develop their industrial park business in Indonesian from 2007.

Table 2. Description of 3 Chinese industrial park investment

\begin{tabular}{lll}
\hline \multicolumn{1}{c}{ Cooperation Zone } & Investment/ income & Main enterprise \\
\hline $\begin{array}{l}\text { China-Indonesia Economic and } \\
\text { Trade Cooperation Zone (KITIC) }\end{array}$ & Investment value of 0.65 billion US dollars & In 2018, 23 enterprises \\
\hline $\begin{array}{l}\text { Indonesia Morowali Industrial } \\
\text { Park }\end{array}$ & Total investment value of 4 billion US dollars & $\begin{array}{l}\text { 6 enterprises, including PT Sulawesi } \\
\text { Mining Investment and Indonesia } \\
\text { Guangqing Ferronickel Industry Co. }\end{array}$ \\
& A & LTD \\
\hline $\begin{array}{l}\text { China-Indonesia Julong } \\
\text { Agricultural Industry Cooperation } \\
\text { Zone }\end{array}$ & A total in- vestment of 1.245 billion US dollars & 12 upstream and down- stream \\
\end{tabular}

Source : Tao et al (2018)

Table 2 show Chinese Industrial Park in Cikarang, West Java Province is focused on industrial land sales because the site's location is close to Jakarta as the economic and government core. Chinese investors are very mindful to invest their resources, for example in two other industrial parks in the field of natural resource production built in the region where the product originates from being preferable so that in addition to finding the best raw materials, the choice of these locations can also save the cost of the distribution of raw materials. 


\section{Discussion}

\section{Sustainable Development Prospect}

\section{Social Progress}

One process of progress in an industrial area is social change. With the changes in the structure of the industrial estate community resulting in changing also various social dimensions within the community, from the three perspectives that have used in analyzing the problem of social change, it can proposed a few simple conclusions of changes that have occurred, namely; functional structural, conflict and symbolic interaction perspectives (Umanailo, 2019).

Functional Structural Perspective. Thera are two manifest in this view such as manifest function and latent function. The manifest function is the desired function, latent is undesirable. So in the existing structure, things that are not relevant are also latent dysfunction affected functionally and dysfunctionally. Merton shows that a dysfunctional structure will always exist (Lauer, 1993).

This personal action is a rational social act in which the goal or objective is achieved by the best means. Not individual behavior is the most important factor, but social standards and values that guide and regulate conduct. Objective conditions, combined with a collective commitment to value in Indonesia's industrial park, will lead to a particular type of social action. Three systems are influenced by individuals and groups: social, cultural and personality systems. Based on their status and role, we can link people to their social systems. In each social system, An individual holds a certain position or status and acts or acts according to the rules or standards of the system, and his or her personality type also affects his/her behavior.

Conflict Perspectives People are generally free, rational, and aesthetic-like creatures. His presence, however, also involves people oppressed by human power itself. In industrial organisations, the creation of a capitalist system oppresses people and causes them to compete with other people. The intensity of the disagreement can have significant impacts on wealth, economic status and social status, although not class determinants.

He put forward the following proposition: "the lower the correlation between power position and other aspects of socioeconomic status, the lower disagreement intensity, and vice versa". In other words, groups who enjoy relatively high economic status are less likely to engage in violent conflicts with power structures than those who excluded from socioeconomic status and power. In society the contradiction cannot be eliminated. The opposition is functional for the development and change of social structure. The most important thing is that the opposition regulated through institutionalization rather than attempts to suppress it (Pei, 2012).

Perspective on Symbolic Interaction Every living person will react to the existing symbols (Scott, 2012). defines formalized formalized formalized formalized formalized formalized formalized formalized As an individual assessment reacts to a physical stimulus. Individual understanding of symbols develops as a result of interactions in the community, in which they communicate existing symbols around them, both verbally and nonverbally. Finally, in comparison with other living things, the ability to convey, learn and understand the meaning of symbols makes people distinguishable (animals). The emphasis of people on the direct response of stimulus responses, but on the understanding of the meaning given to the activities of others through the use of symbols, interpretations, will ultimately try to understand one another's intentions and actions, in order to achieve good agreement. 
Khazanah Sosial, Vol. 3 No. 3: 147-159

Industrial Park and Foreign Investment for Sustainable Development in Indonesia

Hasan Mustapa et.al

\section{Environtment Balance}

Industrial estates built to enhance efforts to develop industries that are sustainable, accelerate the growth and competitiveness of industries and investments. In addition to several industrial areas outside Java. There are several groups of industrial estates in Indonesia on the island of Java. There are at least six suburbs and sub-districts called industrial centers. The group seen in the following table 3 .

Table 3. Industrial Estate Group

\begin{tabular}{llll}
\hline \multicolumn{2}{c}{ Position } & \multicolumn{2}{c}{ Area } \\
\hline $\begin{array}{l}\text { Major industrial } \\
\text { centers }\end{array}$ & $\begin{array}{l}\text { In Bodetabek } \\
\text { (Tangerang Regency) and Cikarang (Bekasi Regency). }\end{array}$ \\
\hline $\begin{array}{l}\text { Four other } \\
\text { industrial centers }\end{array}$ & $\begin{array}{l}\text { located outside Jabodetabek (Jakarta-Bogor-Depok-Tangerang-Bekasi) on the outer periphery, including } \\
\text { Serang (Cilegon and Cikande) and Karawang (Jambe and Cikampek Bay) }\end{array}$ \\
\hline
\end{tabular}

Source: Hudalah D, Viantari D, Firman T (2013)

An environmentally friendly industrial park (EIP) is a concrete application of industrial ecology and industrial symbiosis. Industrial symbiosis is an effective measure for balancing energy supply and demand in regional communities. Industrial ecology, which complemented by industrial symbiosis as a tool for driving environmental in(Zhao H, Zhao H, 2017)novation, becomes a policy mechanism to stimulate longterm cultural change. Thus, the concept of industrial ecology implemented at the policy level implemented through the relationship between industrial companies in the same geographical area by building environmentally friendly industrial parks (Kikuchi Y, Kanematsu Y, Ugo M, Hamada Y, 2015)(Daddi T, Iraldo F, Frey M, Gallo P, 2015). The successful implementation of EIP among them can be seen in table 4:

Table 4. Example of a Successful EIP Implementation

\begin{tabular}{|c|c|}
\hline EIP & Explanation \\
\hline $\begin{array}{l}\text { EIP in Lubei in } \\
\text { Shandong } \\
\text { Province in } \\
\text { China }\end{array}$ & $\begin{array}{l}\text { - From a node perspective, the internal characteristics of the EIP industrial metabolic process in Lubei } \\
\text { Province in China are key nodes (cement clinker production), peripheral nodes (ammonia and power } \\
\text { plants), and key pathways in the network (from factories sulfuric acid to the ammonium phosphate plant } \\
\text { for the cement clinkers production. }\end{array}$ \\
\hline $\begin{array}{l}\text { EIP in } \\
\text { Kalundborg } \\
\text { Denmark }\end{array}$ & $\begin{array}{l}\text { - EIPs in Kalundborg Denmark have reused and recycled resources to produce economic and } \\
\text { environmental benefits. } \\
\text { - The symbiosis between the local community and EPI in Kalundborg has several advantages such as a } \\
\text { significant reduction in energy consumption, a reduction in sulfur dioxide (SO2) and carbon dioxide } \\
\text { (CO2) emissions, as well as increasing the tconventional waste transformation into raw materials in } \\
\text { other processes. } \\
\text { - Since its establishment, EIPs in Kalundborg have managed to save more than } 1.2 \text { million m } 3 \text { of water, } \\
\text { and } 30 \text { thousand tons of fossil fuels. The EIP also reused 70,000 tons of fly ash and reduce more than } \\
130,000 \text { tons of } \mathrm{CO} 2 \text { emissions. }\end{array}$ \\
\hline $\begin{array}{l}\text { South Korea EIP } \\
\text { pilot projects }\end{array}$ & $\begin{array}{l}\text { - several projects involving energy networks generate high positive environmental performance through } \\
\text { mitigation of greenhouse gas emissions. } \\
\text { - The acid / alkali solution recycling project also showed remarkable social results due to the network } \\
\text { formed diversity and the active participation of the company. }\end{array}$ \\
\hline
\end{tabular}

Source: Jung S, Dodbiba G, Chae SH (2013), Zhang Y, Zheng H, Yang Z, Liu G (2015) and Zhao H, Zhao H (2017)

Since systematic monitoring of industrial pollution has been limited thus far, there are a number of focuses that can be observed in observing the impact of industrial policy on the environment in general, such as (1) the industrial activity composition; i.e. high or low pollutant industry; (2) the scale of industrial activity; and (3) demand and supply for pollution reduction efforts.

The dominant industrial policy from 1975 to 1981 was one of import substitution. The government allows large-scale natural resource extraction and uses the proceeds to support and protect the development of large state-owned enterprises in heavy metals and basic chemicals. These policies have the potential to encourage industrial sector development, thereby driving the majority of the economy's industrial sectors. However, because the majority of these industries are relatively large and highly 
polluted, the level of industrial pollution intensity increases significantly in the absence of environmental regulations.

A national environmental impact management agency (Badan Pengendalian Dampak Lingkungan, or BAPEDAL) was established in June 1990 by Presidential Decree No. 23. Several industrial environmental policies have been implemented since then. As shown in Table 5, the overall program has a less significant impact on pro-environmental behavior changes.

Table 5. Government Environtmental Policy Weakness

\begin{tabular}{|c|c|}
\hline Environtmental Policy & Weakness \\
\hline $\begin{array}{l}\text { In } 2002 \text {, the Ministry of Environment } \\
\text { revived the PROPER program with a } \\
\text { more comprehensive goal. }\end{array}$ & $\begin{array}{l}\text { - PROPER is basically an environmental ranking program that acts as a simple } \\
\text { environmental certification. The PROPER program began in June } 1995 \text { as an } \\
\text { alternative environmental policy developed by the Department of the } \\
\text { Environment. } \\
\text { - Most companies, through their association, negotiate with Bank Indonesia not to } \\
\text { consider their PROPER rating in their financial performance analysis and argue } \\
\text { that the Ministry of Environment needs to give more facilities to dispose of toxic } \\
\text { waste before it included in the PROPER evaluation of how the company handles its } \\
\text { toxic waste. }\end{array}$ \\
\hline
\end{tabular}

Source: Resudarmo \& Irhamni (2008)

Although concerns about environmental degradation began to emerge in the late 1970s, serious efforts to reduce the increase in the level of new industrial pollutants began in the early 1990s. Various industrial environmental policies have been implemented, but even if they are effective, the scale is too small. During the 1997-98 economic crisis, governments and the private sector focused on efforts to assist industries in surviving the crisis while ignoring the need to control their pollution. At the macro level, industrial policy during this period was marked by various reforms to further liberalize the economy in order to attract new FDI. At the micro level, industrial policy focuses on a variety of initiatives aimed at increasing the competitiveness of the country's industrial activities.

It recommended that strict national environmental regulations be implemented in order to avoid attracting the majority of new capital investment in high-polluting industries, as was seen in the 1980s and 1990s. Efforts were made in the early 2000s to re-establish industrial environmental policies, but the scale has been relatively limited thus far. The outcomes of this policy must be carefully monitored in order to maximize the chances of successful industrial development and environmental protection.

Pollution control, investment security, infrastructure availability, industrial tourism, and industrial competitiveness are all important factors in the environmental management of industrial estates. A scenario known as new urbanism has a high likelihood of being implemented in the future. This scenario aims for a long-term balance of economic growth and environmental protection. In terms of environmental protection, the use of modern technology can reduce raw material consumption and greenhouse gas emissions (Sjaifuddin, 2018). 
Khazanah Sosial, Vol. 3 No. 3: 147-159

Industrial Park and Foreign Investment for Sustainable Development in Indonesia

Hasan Mustapa et.al

\section{Economic Growth}

For increasing economic growth, industrial park development through foreign direct investment expected bring some advantages such as the labor absorption increasing and exchange and improvement of science and technology from investor countries such as China, Japan, etc.

Increased Labor Absorption. FDI has a strong influence on economic developments and has been demonstrated on different continents in many countries. The government is trying to issue investment regulations to boost the rate of foreign capital, and the latest innovation is that the Indonesian government has pushed and strengthened the "one-stop-shop" (OSS) of investment, established the "electronic traceability system" to publish online bidding procedures and information on financing, to promote foreign investment by simplifying it. President Joko Widodo's release of OSS Central Government on 26 January 2015 is a remarkable moment in improving business and climate investment, especially in licensing services.

Twenty-two ministries were formed as coordinating and delegated departments at IICB. The OSS system is socialized with local governments to prevent conflicting legislation. Eventually, by the end of 2016, all provinces and 514 cities and districts in Indonesia were fully integrated into OSS. One of OSS's goals is to promote the spread of investment beyond Java island, So it can cut through the bureaucracy without the central ministry having to carry out a complicated licensing process (Zeng et al., 2018).

With the ease of investment, the burden of Indonesian state problems such as the issue of unemployment and jobs in the region around industrial parks is expected to be rising. It was demonstrated positively in Song Tao's research, which claimed that more than 20,000 direct jobs and about 10,000 indirect jobs were generated for Indonesia with the establishment of Chinese Industrial Park in Morowali Indonesia, absorbing the investment flow in the region. More than 10,000 Indonesian workers have been hired to date; the subsequent purchases of over 5,000 motorcycles have shown that they have become accustomed to working and living there (Tao et al., 2018). It is also an opportunity in Vietnam where investment flows produced indirect jobs of 330,000 in 1995 jumped 3.6 million in 2017 (Ha, 2019), and Chinese companies played a significant role.

Exchange and improvement of science and technology. With the creation of industrial parks in the city, foreign workers who have the experience to use new technology from their home country and that is new to local workers in the factory will immediately be brought in. In this way, skills and knowledge of local workers will increase. However, many foreign companies also provide local workers with educational and training facilities to help operate their industries.

\section{CONCLUSION}

With a sustainable development approach, it is seen that basically foreign investment that builds several industrial estates in Indonesia is expected to have a positive impact, especially in terms of the economy. However, based on the results of the discussion, it is clear that the development of industrial estates through foreign investment has a significant effect on economic growth but creates problems in social change and environmental sustainability. The success of environmentally friendly industrial estates in cities such as Shandong, China; Kalundborg, Denmark and South Korea cannot yet be adopted in Indonesia.

\section{REFERENCES}

Albarran, A. B. (2016). The media economy. Routledge. 
Arrow, K., \& All., E. (2012). Sustainability and the Measurement of Wealth. Environment and Development Economics, 17(3), 317-53.

Athukorala, P. P. A. W. (2003). The Impact of Foreign Direct Investment for Economic Growth : A Case Study in Sri Lanka The Impact of Foreign Direct Investment for Economic Growth : A Case Study in Sri Lanka. 092, 1-21.

Bank, W. (2019). Indonesia Overview.

Beckerman, W. (2017). 'Sustainable development': is it a useful concept? In The Economics of Sustainability (pp. 161-179). Routledge.

BPS. (2019a). Indonesia Economic Growth.

BPS. (2019b). Statistical Yearbook of Indonesia 2019 (S. of S. C. and Publication (ed.)). Indonesian Bureau of Statistics.

Daddi T, Iraldo F, Frey M, Gallo P, G. V. (2015). Regional policies and eco-industrial development: the voluntary environmental certification scheme of the eco-industrial parks in Tuscany (Italy). Journal of Cleaner Production, 114, 62-70. https://doi.org/10.1016/j.jclepro.2015.04.060

Dahmus, J. B. (2014). Can efficiency improvements reduce resource consumption? Journal of Industrial Ecology, 18(6), 883-897. https://doi.org/10.1111/jiec.12110

Dariah, A. R., \& All., E. (2019). Framework of sustainable development planning in Indonesia. Journal of Physics: Conference Series. https://doi.org/10.1088/17426596/1375/1/012028

Elliott, J. (2012). An introduction to sustainable development. Routledge.

Forte, R., \& Moura, R. (2013). The effects of foreign direct investment on the host country's economic growth: theory and empirical evidence. The Singapore Economic Review, 58(03), 1350017.

Gossling-Goidsmiths, J. (2018). Sustainable development goals and uncertainty visualization. University of Twente.

Ha, L. T. (2019). Chinese FDI in Vietnam : Trends, Status and Challenges. ISEAS Yusof Ishak Institute Journal, 34, 1-10.

Hudalah D, Viantari D, Firman T, W. J. (2013). No Title. Industrial Land Development and Manufacturing Deconcentration in Greater Jakarta, 34(7), 950-971. https://doi.org/10.1080/02723638.2013.783281

IICB. (2019). Domestic and Foreign Direct Investment Realization Indonesia Invetment Coordinating Board.

Jufrida, F., Syechalad, M. N., \& Nasir, M. (2016). Analisis pengaruh investasi asing langsung (FDI) dan investasi dalam negeri terhadap pertumbuhan ekonomi Indonesia. Jurnal Perspektif Ekonomi Darussalam, 2(1), 54-68.

Jung S, Dodbiba G, Chae SH, F. T. (2013). A novel approach for evaluating the performance of ecoindustrial park pilot projects. Journal of Cleaner Production, 39, 50-59. https://doi.org/10.1016/j.jclepro.2012.08.030

Kambono, H., \& Marpaung, E. I. (2020). Pengaruh Investasi Asing Dan Investasi Dalam Negeri Terhadap Perekonomian Indonesia. Jurnal Akuntansi, 12(1), 137-145.

Kikuchi Y, Kanematsu Y, Ugo M, Hamada Y, O. T. (2015). No Title. Industrial Symbiosis Centered on a Regional Cogeneration Power Plant Utilizing Available Local Resources. Journal of Industrial Ecology, 20(2), 276-288. https://doi.org/10.1111/jiec.12347

Kurtishi-Kastrati, S. (2013). The Effects of Foreign Direct Investments for Host Country's Economy. European Journal of Interdisciplinary Studies, 5(1).

Lauer, R. H. (1993). Perspectives on Social Change. Rineka Cipta.

Lipsey, R. E. (1999). The Role of Foreign Direct Investment in International Capital flows (No. 7094; April). 
Maelani, R., Mustapa, H., \& Saifullah, I. (2019). Indonesian Human Progressivism: Human Resources Quantity in Educational Philosophy Perspective. Jurnal Pendidikan Universitas Garut, 13(1 (December)), 86-102.

Mehic, E., Silajdzic, S., \& Babic-Hodovic, V. (2013). The impact of FDI on economic growth: Some evidence from Southeast Europe. Emerging Markets Finance and Trade, 49(sup1), 5-20.

Mulya, M. M. (2015). Investasi Asing Langsung (Foreign Direct Investment) Sektor Industri Manufaktur Teknologi Tinggi Dan Rendah Di Indonesia. UNIVERSITAS AIRLANGGA.

Pei, M. (2012). China and East Asian Democracy: Is CCP Rule Fragile or Resilient? Journal of Democracy, 23(1), 27-41.

Resudarmo, B. P., \& Irhamni, M. (2008). Indonesia' s industrial policy reforms and their environmental impacts. Journal of the Asia Pacific Economy, 13 (4 (November)), 426-450. https://doi.org/10.1080/13547860802364752

Salanto, F. (2015). Indonesia Industrial Estate Directory 2015/2016 A Guide for Investors. IIED.

Scott, J. (2012). Social Theories. Pustaka Pelajar.

Sjaifuddin, S. (2018). Environmental management prospects of industrial area : a case study on MCIE, Indonesia. Business: Theory and Practice, October. https://doi.org/10.3846/btp.2018.21

Su, Y., \& Liu, Z. (2016). China Economic Review The impact of foreign direct investment and human capital on economic growth : Evidence from Chinese cities is. China Economic Review, 37, 97-109. https://doi.org/10.1016/j.chieco.2015.12.007

Suh, Y., Seol, H., Bae, H., \& Park, Y. (2014). Eco-efficiency based on social performance and its relationship with financial performance. Journal of Industrial Ecology, 18(6), 909-919. https://doi.org/https://doi.org/10.1111/jiec.12167

Tao, S., Weidong, L. I. U., Zhigao, L. I. U., \& Yeerken, W. (2018). Chinese overseas industrial parks in Southeast Asia : An examination of policy mobility from the perspective of embeddedness. Journal of Geographical Sciences, 28(17), 1288-1306. https://doi.org/0.1007/s11442-0181526-5

Ukaga, U., Maser., C., \& Reichenbach, M. (2011). Sustainable development: principles, frameworks, and case studies. International Journal of Sustainability in Higher Education, 12(2). https://doi.org/10.1108/ ijshe.2011.24912bae.005.

Umanailo, M. C. B. (2019). Struktur perubahan sosial dalam masyarakat industri (Issue October). https://doi.org/10.31219/osf.io/75rwj

UNCTAD. (2017). ASEAN Investment Report 2017 (50th ed.). The ASEAN Secretariat.

Weissleder, L. (2009). Foreign Direct Investment in the Agricultural Sector in Ethiopia. Ecofair Trade Dialogue, 12(Discussion Paper).

Zeng, G., Zhao, H., \& Hu, H. (2018). Report on Construction and Development of China's Overseas Industrial Parks under the "Belt And Road" Initiatives. China Social Sciences Press.

Zhai, T. T., \& Chang, Y. C. (2019). Standing of environmental public-interest litigants in China: Evolution, obstacles and solutions. Journal of Environmental Law, 30, 369-397. https://doi.org/10.1093/jel/eqy011

Zhang Y, Zheng H, Yang Z, Liu G, S. M. (2015). Analysis of the industrial metabolic processes for sulfur in the Lubei (Shandong Province, China) eco-industrial park. Journal of Cleaner Production, 127-138. https://doi.org/10.1016/j.jclepro.2014.01.096

Zhao H, Zhao H, G. S. (2017). Evaluating the comprehensive benefit of eco-industrial parks by employing multi-criteria decision making approach for circular economy. Journal of Cleaner Production, 142, 2262-2276. https://doi.org/10.1016/j.jclepro.2016.11.041 